\title{
Towards the Improvement of the Writing Process Using the Focus on Form Episodes: With Reference to Taif University Preparatory Year
}

\author{
Sawsan M.A. Ahmed ${ }^{1}$ \\ ${ }^{1}$ Taif University, Kingdom of Saudi Arabia \\ Correspondence: Sawsan M.A. Ahmed, Taif University, Kingdom of Saudi Arabia
}

Received: October 23, 2015

Accepted: November 11, 2015

Online Published: November 30, 2015

doi:10.5430/elr.v4n4p23

URL: http://dx.doi.org/10.5430/elr.v4n4p23

\begin{abstract}
In spite of the abundance of research dealing with the writing skill, the literature has revealed great inadequacy in the methods of teaching writing. However, recent research in applied linguistics has shown revitalization in form-oriented instruction and it has gained popularity in practice. One of those innovative methods is one that makes use of focus on form episodes (FFEs) which have been shown to have a positive effect on the development of English as a Foreign Language (EFL). Such methods were designed to put emphasis on the teaching of from. A random sample of 84 students was divided into two groups where the experimental group was taught writing using the focus on form method whereas the control group was taught using a mixture of traditional EFL teaching methods. The sessions were audio taped and analyzed. Two kinds of input were distinguished, teacher input as well as peer input. Both kinds were divided into preemptive and reactive. A noticeable improvement was observed in the writing of the experimental group. It showed how input can be used to help learners to internalize grammatical rules as learners produced less erroneous structures in their subsequent writings.
\end{abstract}

Keywords: (FFEs), Feedback, Interaction, Negotiation and SLA

\section{Introduction}

The (FFEs) method is based on the level at which choices are made about teaching the skill of writing. It describes the content and the order in which the content is presented. Researchers define the (FFEs) method as a suggested method of teaching writing which involves improving the writing process based on the learners' level. It aims at improving learners' accuracy as far as the production of writing is concerned.

It is suggested that the implementation of the (FFEs) method would improve learners' writing within a shorter period of time. The premise that distinguishes the (FFEs) method is the procedures and tasks involved while teaching writing. These procedures and tasks include the process of explicit grammar teaching; negotiation of meaning and form based on the level of grammar suited to the level of the learner; interaction between teacher and students and students to students in a form of communicative grammar language teaching; and finally, feedback is presented, whether direct or indirect, based on the nature of the learners' errors. How much is presented and when it is presented is a subject of dispute among linguists. Older methods of teaching often call for the use of either emphasis on the communicative aspect of language or emphasis on the structural aspect of language exclusively. Long and Robson (1998) focus on form refers to how attention is allocated..."Focus on form consists of an occasional shift of attention to linguistic code features - by the teacher and/or more students - triggered by perceived problems with comprehension or production" (p. 23).

\section{Background of the (FFEs) Method}

Regarding the traditional theories of language learning and teaching, teachers and practitioners are introduced to a variety of methods of teaching where insistence on form was presented first. Later on, the emphasis was placed on content rather than form. Finally the eclectic methods were introduced where the choice is left to the practitioner whether to emphasize form, function or both.

However, Practitioners find that the teaching of writing presents a daunting task and the emphasis is placed gathering ideas with erroneous structures that teachers find it hard to eradicate. In 2003, Hedge created a seven stage process to enhance the writing process. The methodology of teaching writing she created present a new outlook and created a departure from the traditional approaches. Such a process "comprises planning, drafting and revising" (p. 290). Atwell, however in (1987) created a five step system of writing process; prewriting, drafting, revising, editing, and publishing 
(p.3). Pennington, Brock and Yue (1996) in a study compared two groups. The first practised the process of writing and the second practised traditional language exercises and grammatical accuracy with very little instruction and feedback. The first group achieved higher progress in writing. In the 2000s, Ferris $(2002,2003,2004)$ and Bitchener (2005) indicated that there has been a general awareness that instruction as far as the writing process is concerned and considered as significant in helping learners improve the accuracy of their writing texts.

\section{Theory of Language in the (FFEs) Method}

The (FFEs) method which is indicated by Ellis (2005) distinguished between planned and incidental focus on form. Planned focus on form involves targeting pre-selected linguistic items during a meaning-focused activity, either through input or output. The second kind is the explication of rules as the opportunity arises. Although both types of focus on form might be beneficial for learners (Doughty \& Williams, 1998), their impact may vary. Planned focus on form has the advantage of providing intensive coverage of one specific linguistic item, whereas incidental focus on form provides extensive coverage, targeting many different linguistic items (Ellis et al., 2001a). The first one is the structural view where language is considered as a system of structurally related elements for the coding of meaning. The mastery of these elements is in essence the target of language learning. The second view is the, functional view where language is viewed as a vehicle for the expression of functional meaning. In this sense, the emphasis is on semantic and communicative levels rather than on grammatical characteristics only. The third view is the interaction because language learning is considered as a cumulative process that is learned best through negotiation and interaction.

Norris \& Ortega (2001), indicated that instructions and explication of rules produce "substantial gains in terms of the acquisition of the target structure" (ct. Fotos \& Nassaji (2007, p.11). Their study examined the effects instructions and found them to have been useful. The study showed that explicit instructional techniques yielded more positive effects than those involving implicit techniques. The effectiveness as far as a treatment is concerned, depends on the methodological approaches adopted. In evaluating the tasks achieved following Fotos \& Ellis (1991), Fotos (1993), and Leow (2001) it is noticed that some of the tasks were incorporated more explicitly and that raising consciousness is one of these tasks, whereby, the task objective given to learners is to solve a grammar problem using the target structure or to generate grammar rules. The reason for not handing the right forms directly to learners, but providing them with corrective feedback and allowing them to analyze their errors is that it gives them the space to interact, negotiate. Such a method is called "the garden path" where the learner is even lead to make the errors. Both kinds of errors, whether they are interlanguage i.e as a result of mother tongue interference, or interlanguage resulting from the learners' learning process such as overgeneralization, learners are left to conclude the rules for themselves which makes learning more memorable. (Long, 1991) Long and Robinson (1998) argue that the responsibility of helping learners attend to and understand problematic L2 grammatical forms falls not only on their teachers, but also on their peers(as cited in Poole 2005).

\section{Corrective Feedback and its Role}

Both Lyster (2004) and Ferris (2006) suggest that corrective feedback urges the learners to correct his or her own error which is effective in promoting acquisition. Regarding the role of student to student interaction, Gass and Varonis (1994) indicated multiple incidents of learners calling other learners' attention to their errors. The interactional process, whether it is negotiated interaction, interactional feedback, noticing gaps in knowledge by learners, while writing can direct the learners' attention to structures that might have been stored in their memory (implicit knowledge) that they have temporarily forgotten. The teacher's role is the activation of this knowledge. Different types of interactions promote development and lead to actual improvement in learners' knowledge in the long term. In designing the (FFEs), the interaction in a form of dialogue between learners themselves and the teacher is basic in performing the writing task. Having that space for interaction can create a favourable context in which learners can participate actively. This interaction can demonstrate what L2 learners can do and what erroneous structures can emerge, this gives teachers ideas how much time to designate to eradicate those errors.

\section{The Research Question}

Based on the literature review it is concluded that the first year students can benefit from:

1. Using (FFEs) in improving their writing and that includes:

a. According to the researcher's experience errors are predicted, found and classified.

b. Using the explication of rules as a way of recognizing errors. 
c. Recognizing that the learning process is cumulative, therefore using negotiation and interaction as a means of error realizing.

d. providing feedback as needed based on learner's errors.

\section{The Sample}

The sample of the study consists of 84 female students of first year at Taif University. The group was divided into two groups. The first is considered as an experimental group containing 42 students and a control group of 42 students. First year students are called preparatory year students. They have studied English for seven years prior to entering university. They have been taught using the communicative method where the focus is rarely placed on form. The sample is selected randomly and is given freedom to predict and request grammar or lexical help throughout the writing process. The control group received generic explanation.

\section{The Method}

A statistical analysis of the errors pre and post experiment of both groups will be provided where the effect of FFEs in eliminating errors as far as the experimental group is concerned.

\section{The Group Task}

The group is given four writing tasks for each of the four classes of ranging from describing a wedding party they have been to, a birthday party they have been to, describing some ritualistic activities that were performed in them. Other topics include describing oneself and family member. They were seated in a special table. The researcher focused on FFEs and tape recorded all the audible proceedings while the group was performing the writing tasks. The FFEs are divided into student-teacher and student-student interactions. The FFEs later are analysed to find out the distribution and type of different kinds of FFEs.

The recordings are transcribed shortly after the class so that the inaudible details can be recalled and documented. Four classes were used in the study where two sessions of every class were recorded. Every recording lasted 50 minutes. The time at the beginning of the class where explanation of the details of requirements presented to the students were not recorded. The transcription of the class interaction was done by the researcher. The recordings were coded to identify instances of FFEs.

\section{The Initial Task}

An initial writing task was given to both groups to determine the compatibility of the two groups (write about your favorite possession). The text that was required was about 200 words. The task has proven that the two groups are compatible as can be seen from table 1 .

Table 1. Kinds and instances of errors in both groups in pre experiment writing

\begin{tabular}{lllll}
\hline Experimental group & & \multicolumn{3}{l}{ Control group } \\
\hline Kind of errors & errors & Rate of errors & errors & Rate of errors \\
\hline punctuation & 270 & $5.6 \%$ & 289 & $6 \%$ \\
tense & 204 & $4.2 \%$ & 212 & $4.1 \%$ \\
a/an & 103 & $2.1 \%$ & 102 & $2.1 \%$ \\
Subject-Verb & 98 & $2 \%$ & 101 & $2.1 \%$ \\
agreement & & & & \\
pronoun & 98 & $2 \%$ & 102 & $2.1 \%$ \\
Spelling & 87 & $1.8 \%$ & 72 & $1.5 \%$ \\
Wrong word & 66 & $1.3 \%$ & 62 & $1.2 \%$ \\
Plural noun & 50 & $1 \%$ & 63 & $1.3 \%$ \\
\hline
\end{tabular}

As can be seen the two groups are compatible when it comes to knowledge of grammar and lexis.

Throughout the designated classes for writing the experimental group was given special attention where their queries were answered on the need basis. In the writhing process there were many incidents of FFEs spreading from grammar vocabulary, pronoun, spelling. The experimental group had a (preemptive) focus on form from the researcher as well as from their peers in addition to (reactive) focus on form where the students were given corrective feedback. The preemptive focus on form entails incidents where the researcher or students ask about a specific form. 
Table 2. Frequency and type of preemptive and reactive corrections incidents

\begin{tabular}{lllllllll}
\hline Kinds of FFEs & Researcher & preemptive & reactive & $\%$ & peer & preemptive & reactive & $\%$ \\
\hline punctuation & 33 & 5 & 22 & $81.8 \%$ & 6 & 3 & 3 & $18 \%$ \\
tense & 25 & 9 & 10 & $76 \%$ & 6 & 1 & 5 & $24 \%$ \\
a/an & 20 & 9 & 11 & $48 \%$ & 5 & 2 & 3 & $24 \%$ \\
Subject-Verb agreement & 19 & 8 & 6 & $48 \%$ & 3 & 1 & 2 & $27.3 \%$ \\
pronoun & 16 & 8 & 4 & $76 \%$ & 4 & 0 & 4 & $30.7 \%$ \\
Spelling & 13 & 2 & 6 & $69.2 \%$ & 4 & 1 & 3 & $30.7 \%$ \\
Wrong word & 12 & 2 & 10 & $100 \%$ & 0 & 0 & 0 & $0 \%$ \\
Plural nouns & 10 & 3 & 7 & $100 \%$ & 0 & 0 & 0 & $0 \%$ \\
\hline
\end{tabular}

Table 3. Subsequent writing errors in the experimental group (across the 42 students)

\begin{tabular}{lccc}
\hline Grammar \& lexical points & Erroneous & $\%$ & rate of improvement from the first task \\
\hline punctuation & 80 & $1.6 \%$ & $4 \%$ \\
tense & 26 & $0.5 \%$ & $3.7 \%$ \\
a/an & 45 & $0.92 \%$ & $1.18 \%$ \\
Subject-Verb agreement & 37 & $0.77 \%$ & $1.23 \%$ \\
pronoun & 23 & $0.47 \%$ & $1.53 \%$ \\
Spelling & 50 & $1.04 \%$ & $0.75 \%$ \\
Wrong word & 15 & $0.31 \%$ & $1.17 \%$ \\
Plural nouns & 15 & $0.31 \%$ & $0.87 \%$
\end{tabular}

Table 4. Subsequent writing errors in the control group (across the 42 students)

\begin{tabular}{lccc}
\hline Grammar \& lexical points & Erroneous & $\%$ & rate of improvement from the first task \\
\hline punctuation & 98 & $2 . \%$ & $4.0 \%$ \\
tense & 76 & $1.5 \%$ & $2.5 \%$ \\
a/an & 77 & $1.60 \%$ & $0.5 \%$ \\
Subject-Verb agreement & 69 & $1.4 \%$ & $0.6 \%$ \\
pronoun & 61 & $1.27 \%$ & $0.83 \%$ \\
Spelling & 51 & $1.06 \%$ & $0.5 \%$ \\
Wrong word & 37 & $0.77 \%$ & $0.43 \%$ \\
Plural nouns & 23 & $0.47 \%$ & $0.83 \%$
\end{tabular}

The statistics of the better sample is taken from the third writing which is considered the middle specimen of the two groups.

The two groups were instructed to allow peers to inspect each others' work and ask for help in writing freely. Through the writing classes the researcher felt the urgency when learners needed the help of their peers and how they used it instantly and in subsequent writings.

Here is an instant:

Student 1: I am looking for a word to describe getting a gift for my friend's birthday.

Student 2: Why ...eh .. not buy

Teacher: Why don't you buy....

Student 2: Why don't you buy him a video game?

Student 1 wrote: I asked my friend for ideas for a gift to buy for my friend's birthday. He said "Why don't you buy him a video game? 


\section{Analysis and Recommendation}

The research shows that there were as many preemptive focus-on-form episodes (FFEs) as reactive FFEs. The majority of the preemptive FFEs were initiated by researcher-who acted as a teacher for the experimental group- rather than the students. However both have proven to be invaluable as far as resonance. Both were incorporated into the production of the students' own writing, especially when the FFEs were student initiated. The preemptive FFEs were direct and explicit in nature. Interactions were varied in length but writers felt when the need arouse they were stimulated by peers and their instructor. Nassaji (2007) discussed how knowledge is represented and organized in the mind and what role does negotiating it with peers play as far as rules comprehension and interpretation. He described negotiating meaning as a means of comprehension optimizer and that contribute to the creating "schema". The role of creating schema is paramount in moving knowledge from theory to theory to application. The role of explication has manifested itself in the FFEs sessions clearly as a an invaluable part of Adult ESL teaching and learning.

\section{Pedagogical Implication}

As can be seen and asserted by numerous studies, any language input can be beneficial to students. Both explicit and implicit and considering both simple and complex grammatical instruction. Learners can use explication as a means of learning and it can make a difference in assimilation and synthesis of the rules.

\section{Conclusion}

Taking the social nature and learning and how valuable prompts given by the peers, it becomes apparent that the learner has to move about the stages of the learning process using cognition. Furthermore, due to the cumulative nature of learning, one can assume that peer help is paramount when it comes to instilling knowledge and allowing learners to apply the accumulated knowledge during the process if writing.

\section{Ideas for Future Research}

As researchers realize the role of peer help on learning and creating schemas, the use of the social media can be utilized as instantaneous help can be elicited through venues such as twitter. Instructors can measure the amount of improvement by creating hashtags where peer help can be elicited. Similarly, facebook messages and other social media venues can be used in an out of class settings. At the end of the day the researchers can collect the data and check for improvement.

\section{References}

Atwell, N. (1987). In the middle: Writing, reading and learning with adolescents. Portsmouth, NH: Heinemann Educational Books.

Bitchener, J. S. Young, \& D. Cameron, (2005). The effect of different type of corrective feedback on ESL student writing. Journal of Second Language writing, 14, 33-41. http://dx.doi.org/10.1016/j.jslw.2005.08.001

Doughty, C. \& Williams, J. (1998). Focus on form in classroom second language acquisition. New York: Cambridge University Press.

Ellis, N. (2005). At the interface: Dynamic interactions of explicit and implicit Language knowledge. Studies in Second Language Acquisition, 27, 305-352. http://dx.doi.org/10.1017/s027226310505014x

Farrokhi, F. \& Gholami, J. (2007). Reactive and preemptive language related episodes and uptake in an EFL class. Asian EFL Journal 9(2), 58-92.

Ferris, D. R. (2006). Does error feedback help student writers? New evidence on the short-and long-term effects of written error correction. In K. Hyland, \& F. Hyland (Eds.), Feedback in second language writing: Contexts and issues (pp. 81-104). Cambridge, UK: Cambridge University Press. http://dx.doi.org/10.1017/CBO9781139524742.007

Fotos, S. (1993). Consciousness raising and noticing through focus on form: Grammar task performance versus formal instruction. Applied Linguistics, 14(4), 385-407. http://dx.doi.org/10.1093/applin/14.4.385

Fotos, S., \& Ellis, R. (1991). Communication about grammar: a task based approach. TESOL Quarterly, 25(4), 605-628. http://dx.doi.org/10.2307/3587079

Fotos, S., \& Nassaji, H. (Eds.). (2007). Form-focused instruction and teacher education Studies in honor of Rod Ellis. UK: Oxford University Press.

Gass, S. M., \& Varonis, E. M. (1994). Input, interaction, and second language Production. Studies in Second Language Acquisition, 16(3), 283-302. http://dx.doi.org/10.1017/S0272263100013097 
Hedge, T. (2003). Teaching \& learning in the language classroom. London: Oxford University Press.

Hendrickson, J. M. (1978). Error correction in foreign language teaching: Recent theory research and practice. The Modern Language Journal, 62(8), 387-398.

Herschensohn, J. (2000). The Second time around: Minimalism and L2 acquisition. Amsterdam Philadelphia: Benjamins. http://dx.doi.org/10.1075/lald.21

Herschensohn, J. (2001). Missing inflection in second language French: accidental infinitives and other verbal deficits. Second Language Research, 17(3). http://dx.doi.org/10.1191/026765801680191514

Leow, R. P. (2001). Attention, awareness and foreign language behavior. Language Learning. 51, $113-155$. http://dx.doi.org/10.1111/j.1467-1770.2001.tb00016.x

Loewen, S. (2003). Variation in frequency and characteristics of incidental focus on Form. Language Teaching Research, 7, (3). http://dx.doi.org/10.1191/13621688031r129oa

Long, M., \& Robinson, P. (1998). Focus on form: Theory, research, and practice. In C. Doughty \& J. Williams (Eds.), Focus on form instruction in classroom second language acquisition (pp. 15-63). Cambridge: Cambridge University Press.

Long, M. (1991). Focus on form: A design feature in language teaching methodology. In K. de Bot, R. Ginsberg, \& C. Kramsch (Eds.), Foreign language research in cross-cultural perspective (pp. 39-52). Amsterdam: John Benjamins. http://dx.doi.org/10.1075/sibil.2.07lon

Krashen, S. D. (1982). Principles and practice in second language acquisition. Oxford: Pergamon.

Lyster, R. (2004). Differential effects of prompts and recasts in form-focused instructions. Studies in Second Language Acquisition, 26, 399-432. http://dx.doi.org/10.1017/s0272263104263021

Nassaji, H. (2007). Schema theory and knowledge-based processes in second language reading comprehension: A need for alternative perspectives. Language Learning, http://dx.doi.org/10.1111/j.1467-9922.2007.00413.x

Norris, J. \& Ortega, L. (2000). Effectiveness of L2 instruction: A research synthesis and quantitative meta-analysis. Language Learning, 50, 417-528. http://dx.doi.org/10.1111/0023-8333.00136

Oliver, R., (2000). Age differences in negotiation and feedback in classroom and pair work. Language Learning, 50, (1). http://dx.doi.org/10.1111/0023-8333.00113

Pienemann, M. (2005). Cross-linguistic aspects of processability theory. Amsterdam: Benjamins. http://dx.doi.org/10.1075/sibil.30 